\title{
Antibodies to the thyroid gland and to the thyrotrophin receptor in African and Indian thyrotoxic patients
}

\author{
R.K. Desai ${ }^{1}$, I. Jialal ${ }^{1}$, M.A.K. Omar ${ }^{2}$, M.C. Rajput ${ }^{2}$ and S.M. Joubert ${ }^{1}$ \\ ${ }^{1}$ Department of Chemical Pathology, S.A. Medical Research Council Preclinical Diagnostic Chemistry Research \\ Unit, and ${ }^{2}$ Department of Medicine, University of Natal Medical School, Durban, Republic of South Africa.
}

\begin{abstract}
Summary: Sixty two thyrotoxic patients, 34 African and 28 Indian, were studied in order to assess the prevalence of thyroid antibodies and TSH binding inhibitory activity (TBI): 45 had Graves' disease and 17 had toxic nodular goitres. Microsomal and thyroglobulin antibodies were positive more often in Indian than in African patients with Graves' disease (microsomal 52\% vs $37.4 \%, P<0.05$; thyroglobulin $38.1 \%$ vs $4.2 \%, P<0.001)$. Patients with toxic nodular goitres had a lower prevalence of positive microsomal antibodies $(P<0.01)$, but not of thyroglobulin antibodies $(P=0.1)$ when compared with patients with Graves' disease. TBI activity measured by a radioreceptor assay was positive in 43 of the 45 (95\%) patients with Graves' disease and only 1 of the 17 patients (5.9\%) with toxic nodular goitre. It thus appears that TBI activity is a sensitive marker in the diagnosis of Graves' disease and that there is a lower prevalence of thyroglobulin and microsomal antibodies in African patients compared with Indian patients.
\end{abstract}

\section{Introduction}

Although thyrotoxicosis has been reported to be rare in Africans (Dancaster, 1970; Kalk, 1980), several recent reports have challenged this finding (Oliech, 1977; Mulaisho, 1979; Bowry et al., 1984). An earlier publication (McGill, 1971) also suggested that autoimmune or lymphocytic thyroiditis, as assessed by the presence of thyroglobulin or microsomal antibodies, was uncommon in the African thyrotoxic patient. The present study was undertaken to determine the relative frequency of thyroid microsomal and thyroglobulin antibodies in South African Black and Indian patients with Graves' disease and thyrotoxicosis secondary to a multinodular goitre or adenoma. Antibodies to the thyroid stimulating hormone (TSH) receptor were also measured by a recently developed radioreceptor assay (Southgate et al., 1984) which measures the competitive inhibition of ${ }^{125}$ I-TSH binding to thyroid membranes.

\section{Patients}

Sixty two consecutive patients with thyrotoxicosis, 34 African and 28 Indian were studied: 45 had Graves' disease, 24 African and 21 Indian; 17 had toxic nodular goitre, 10 African and 7 Indian.

Correspondence: R.K. Desai, Dept. of Chemical Pathology, University of Natal Medical School, PO Box 17039, Congella 4013, Republic of South Africa.

Accepted: 29 April 1986
Thyrotoxicosis was diagnosed on clinical grounds and confirmed by the measurement of free thyroxine $\left(\mathrm{FT}_{4}\right)$, free triiodothyronine $\left(\mathrm{FT}_{3}\right)$ and, where necessary, the TSH response to thyrotropin-releasing hormone (TRH). Graves' disease was diagnosed on the basis of thyrotoxicosis associated with a smooth goitre and diffuse uptake on thyroid scan. The remaining thyrotoxic patients had nodular goitre as shown by clinical examination and patchy uptake of ${ }^{125} \mathrm{I}$ on thyroid scan.

\section{Methods}

$\mathrm{FT}_{4}, \mathrm{FT}_{3}$ and $\mathrm{TSH}$ were measured by radioimmunoassay (Amersham International, Amersham, United Kingdom). Thyroid microsomal and thyroglobulin antibodies were measured by haemagglutination techniques (Wellcome Diagnostics, London, United Kingdom). The microsomal and thyroglobulin titres were considered positive if agglutination was observed at a minimum dilution of $1: 100$ and $1: 10$, respectively. Antibodies to the TSH receptor were measured in serum by a radioreceptor assay (RSR Ltd, Cardiff, UK). Briefly, the patient's serum was incubated with ${ }^{125} \mathrm{I}$-TSH and thyroid membranes. Samples were centrifuged after the addition of $30 \%$, w/v, PEG in $1 \mathrm{~mol} / 1$ $\mathrm{NaCl}$, and the bound radioactivity was then counted in a gamma counter. The amount of ${ }^{125} \mathrm{I}-\mathrm{TSH}$ nonspecifically trapped in the pellet was determined by replacing the thyroid membranes with $1 \%$ Lubrol in

C The Fellowship of Postgraduate Medicine, 1986 
the reaction mixture. Results were expressed as inhibition of labelled TSH binding (TSH binding inhibition or TBI) and calculated as follows:

$$
100 \times\left[1-\frac{\text { Labelled TSH specifically bound in the presence of test sample }}{\text { Labelled TSH specifically bound in the presence of negative serum }}\right]
$$

The results were expressed as a percentage and found to be less than $15 \%$ in the 40 euthyroid controls tested. Samples were considered positive when TBI was greater than $20 \%$.

\section{Results}

One hundred per cent of the Black South African patients and $90.5 \%$ of the Indian patients with Graves' disease had positive TBI activity. Only $14.3 \%$ of Indian patients and none of the Blacks with toxic nodular goitre had positive TBI activity.

The frequency of positive microsomal and thyroglobulin antibody titres was significantly higher in Indian patients with Graves' disease than African patients (microsomal: $52.3 \%$ vs $37.4 \%, P<0.05$; thyroglobulin: $38.1 \%$ vs $4.2 \%, P<0.001$ ). In both Indian and African patients the prevalence of positive microsomal antibody titres was significantly greater than that of positive thyroglobulin antibody titres (Indians: $52.3 \%$ vs $38.1 \%, P<0.05$; Africans: $37.4 \%$ vs $4.2 \%, P<0.001)$. When patients with Graves' disease were compared with patients with toxic nodular goitres with respect to the percentage of patients with positive antibody titres there was only a significant difference in the frequency of microsomal antibodies (Graves' disease $44.4 \%$; toxic nodular goitre $11.8 \% P<0.01$ ). There were no differences between the 2 groups with regard to thyroglobulin antibodies $(20 \%$ vs $11.8 \%, P=0.1)$.

\section{Discussion}

The overall $95.6 \%$ positivity rate of TBI activity in Graves' disease demonstrates this assay to be a useful marker for this disease. Some workers have reported TBI to be positive in approximately $70 \%$ of patients with untreated Graves' disease (O'Donnel et al., 1978; Sugenoya et al., 1979), but a detection rate of up to $100 \%$ (Southgate et al., 1984) has been reported by others. Possible reasons for the wide variations in the positivity rates of TBI activity in Graves' disease have been previously discussed (Bíró, 1982). These include differences in the sensitivities of the different assay systems used; variations in the clinical state of the patient; and the effects of previous therapy. Moreover, the existence of interfering factors in the serum and the heterogeneity of antibodies to the TSH receptor (Gossage et al., 1983), make it unlikely that all patients with Graves' disease will demonstrate positive TBI activity. All antibodies to the TSH receptor detected by this assay are not necessarily stimulatory and some may even be inhibitory (Gossage et al., 1983). Stimulatory activity of the antibodies can only be confirmed by a bioassay that measures, for example, cyclic AMP (Hinds et al., 1981) or $\mathrm{T}_{3}$ release (Laurberg \& Weeke, 1975) from thyroid slices or cells.

TBI activity has generally been found to be negative in patients with toxic multinodular goitre (O'Donnel et al., 1978; Sugenoya et al., 1979) although Brown et al. (1978) reported positive activity in some patients with toxic and non-toxic multinodular goitre. Positive TBI activity has also been reported in patients with euthyroid ophthalmic Graves' disease (O'Donnel et al., 1978), thyroid carcinoma (Mukhtar et al., 1975), Hashimoto's disease (Sugenoya et al., 1979) and subacute thyroiditis (Strakosch et al., 1978). In the present study, only 1 of $17(5.9 \%)$ patients with toxic nodular goitre had positive TBI activity and, as discussed above, this does not necessarily mean that? this patient has stimulatory antibodies to the TSH receptor.

Microsomal and thyroglobulin antibodies were positive more often in Indians with Graves' disease than in Africans $(P<0.05$ and $P<0.001$, respectively). At least one antibody was detected in $52.3 \%$ of Indians and $38.0 \%$ of Africans with Graves' disease. Mori \& Kriss (1971) reported elevated serum concentrations of microsomal and thyroglobulin antibodies in $98 \%$ and $89 \%$, respectively, of patients with untreated Graves' disease, using sensitive radioimunoassay techniques. However, even with the usage of the less sensitive tanned red cell, complement fixation or haemagglutination inhibition techniques, uniformly higher positivity rates for these antibodies have been reported in Western populations with Graves' disease (Anderson et al., 1967; Amino et al., 1976). In their study on the autoantibody profile in black Kenyans, Bowry et al. (1984) found a lower prevalence of thyroid antibodies in black Kenyan hospital controls and patients with non-toxic smooth and multinodular goitre as compared to Caucasians. A lower prevalence of thyroglobulin antibodies was also found in Kenyans with toxic goitre as compared to Caucasians. In contrast, microsomal antibodies were found with equal frequency $(54 \%)$ in Kenyan 
Blacks and Caucasoids with toxic goitre, in the above study.

In the present study, patients with toxic multinodular goitre were found to have a significantly lower prevalence of microsomal antibodies $(P<0.01)$, but not of thyroglobulin antibodies $(P=0.1)(14.3 \%$ positivity rate of each antibody in Indians and $10 \%$ in Africans), when compared with patients with Graves' disease, though it was higher than the prevalence obtained in healthy South African Indians (5.6\%) and African (0\%) controls (Omar et al., 1986). The lower prevalence of antibodies in patients with toxic multinodular goitre is not surprising since Graves' disease is generally considered to be an autoimmune endocrine disease. However, thyroid growth immun- oglobulins promoting an increase in the size of the thyroid gland have been reported in the sera of patients with multinodular goitre (van der Gaag et al., 1985). This evidence suggests the multinodular goitre may also have an autoimmune basis.

In conclusion, this study demonstrates TBI activity to be a useful marker in the diagnosis of Graves' disease. The findings of a dissociation in the frequencies of the two thyroid antibodies on the one hand and antibodies to the TSH receptor on the other, provide support for the hypothesis of Bowry et al. (1984) that the immunogenetic control of these and related diseases is different in Africans as compared with Caucasians.

\section{References}

AMINO, N., HAGEN, S.R., YAMADA, N. \& REFETOFF, S. (1976). Measurement of circulating thyroid microsomal antibodies by the tanned red cell haemagglutination technique: its usefulness in the diagnosis of autoimmune thyroid disease. Clinical Endocrinology, 5, 115.

ANDERSON, J.W., MCCONAHEY, W.M., ALARCONSEGOVIA, D., EMSLANDER, R.F. \& WAKIM, K.G. (1967). Diagnostic value of thyroid antibodies. Journal of Clinical Endocrinology, 27, 937.

BÍRÓ, J. (1982). Thyroid-stimulating antibodies in Graves' disease and the effect of thyrotrophin-binding globulins on their determination. Journal of Endocrinology, 92, 175.

BOWRY, T.R., MUTURI, I.L., RADIA, R. \& GITAU, W. (1984). Autoantibody profile in thyroid diseases in black Kenyans. Journal of Clinical and Laboratory Immunology, 15, 133.

BROWN, R.S., JACKSON, I.M.D., POHL, S.L. \& REICHLIN, S. (1978). Do thyroid-stimulating immunoglobulins cause non-toxic and toxic multinodular goitre? Lancet, i, 904.

DANCASTER, C.P. (1970). Thyrotoxicosis in the Bantu, with special reference to myopathy. South African Medical Journal, 44, 695.

GOSSAGE, A.A.R., CRAWLEY, J.C.W., COPPING, S., HINGE, D. \& HIMSWORTH, R.L. (1983). Thyroid function and immunological activity during and after medical treatment of Graves' disease. Clinical Endocrinology, 19, 87.

HINDS, W.E., TAKAI, N., RAPOPORT, B., FILETTI, S. \& CLARK, O.H. (1981). Thyroid-stimulating immunoglobulin bioassay using cultured human thyroid cells. Journal of Clinical Endocrinology and Metabolism, 52, 1204.

KALK, W.J. (1980). Atypical features of hyperthyroidism in Blacks. South African Medical Journal, 57, 707.

LAURBERG, P. \& WEEKE, J. (1975). T $_{3}$ release from thyroid slices as an assay for thyroid stimulators. Scandinavian Journal of Clinical and Laboratory Investigation, 35, 723.

McGILL, P.E. (1971). Thyrotoxicosis in the African - clinical and immunological observations. British Medical Journal, 2, 679.

MORI, T. \& KRISS, J.P. (1971). Measurements by competitive binding radio-assay of serum anti-microsomal and anti-

thyroglobulin antibodies in Graves' disease and other thyroid disorders. Journal of Clinical Endocrinology, 33, 688.

MUKHTAR, E.D., SMITH, B.R., PYLE, G.A., HALL, R. \& VICE, P. (1975). Relation of thyroid stimulating immunoglobulins to thyroid function and effects of surgery, radioiodine, and anti-thyroid drugs. Lancet, i, 713.

MULAISHO, C. (1979). Hyperthyroidism at the University Teaching Hospital, Lusaka, Zambia. East African Medical Journal, 56, 617.

O'DONNEL, J., TROKOUDES, K., SILVERBERG, J., ROW, V. \& VOLPE, R. (1978). Thyrotropin displacement activity of serum immunoglobulins from patients with Graves' disease. Journal of Clinical Endocrinology and Metabolism, 46, 770.

OLIECH, J.S. (1977). Thyrotoxicosis at Kenyatta National Hospital, Nairobi. East African Medical Journal, 54, 561.

OMAR, M.A.K:, BOTAZZO, G.F. \& ASMAL, A.C. (1986). Islet cell antibodies in South African Blacks and Indians with insulin dependent diabetes mellitus. Hormone and Metabolic Research, 18, 126.

SOUTHGATE, K., CREAGH, F., TEECE, M., KINGWOOD, C. \& REES SMITH, B. (1984). Receptor assay for the measurement of TSH receptor antibodies in unextracted serum. Clinical Endocrinology, 20, 539.

STRAKOSCH, C.R., JOYNER, D. \& WALL, J.R. (1978). Thyroid stimulating antibodies in patients with subacute thyroiditis. Journal of Clinical Endocrinology and Metabolism, 46, 345.

SUGENOYA, A., KIDD, A., ROW, V.V. \& VOLPÉ, R. (1979). Correlation between thyrotropin-displacing activity and human thyroid-stimulating activity by immunoglobulins from patients with Graves' disease and other thyroid disorders. Journal of Clinical Endocrinology and Metabolism, 48, 398.

VAN DER GAAG, R.D., DREXHAGE, H.A., WIERSINGA, W.M., BROWN, R.S., DOCTER, R., BOTAZZO, G.F. \& DONIACH, D. (1985). Further studies on thyroid growth-stimulating immunoglobulins in euthyroid nonendemic goitre. Journal of Clinical Endocrinology and Metabolism, 60, 972. 